\title{
DAMPAK KERJA SAMA PERDAGANGAN INDONESIA DENGAN EURASIAN ECONOMIC UNION (EAEU) TERHADAP PEREKONOMIAN INDONESIA
}

\section{The Impact of Indonesia-Eurasian Economic Union (EAEU) Trade Cooperation on the Indonesian Economy}

\author{
Deky Paryadi, Aziza Rahmaniar Salam \\ Pusat Pengkajian Kerjasama Perdagangan Internasional, Kementerian Perdagangan-RI, \\ JI.M.I. Ridwan Rais No.5 Jakarta, 10110, Indonesia \\ Email: deckyparyadi@gmail.com
}

\begin{abstract}
Naskah diterima: 10/02/2018; Naskah direvisi: 25/06/2018; Disetujui diterbitkan: 03/12/2018
\end{abstract}
Dipublikasikan online: 31/12/2018

\begin{abstract}
Abstrak
Kawasan Eurasia merupakan wilayah yang penting secara geopolitik dan geostrategi bagi perdagangan Indonesia. Melihat potensi yang dimiliki oleh negara-negara yang tergabung dalam Eurasian Economic Union (EAEU), Indonesia diharapkan dapat memanfaatkan peluang yang terbuka. Penelitian ini bertujuan untuk mengetahui potensi daya saing komoditas serta dampak kerja sama perdagangan Indonesia-EAEU. Metode analisis yang digunakan adalah Trade Complementary Index (TCl), Revealed Symetric Comparative Advantages (RSCA) dan Computable General Equilibrium (CGE) model dengan data dasar GTAP versi 9 menggunakan enam simulasi. Berdasarkan analisis $\mathrm{TCl}$, tingkat kesesuaian ekspor EAEU terhadap struktur impor Indonesia lebih tinggi dibandingkan ekspor Indonesia terhadap struktur impor EAEU. Dengan melihat dampak kerja sama perdagangan IndonesiaEAEU terhadap makroekonomi Indonesia, penurunan tarif bea masuk sebesar $50 \%$ untuk seluruh produk Indonesia dan EAEU merupakan alternatif kebijakan terbaik. Indonesia perlu menjajaki kemungkinan kerja sama dengan EAEU dengan pendekatan berupa eliminasi $50 \%$ pada seluruh pos tarif secara bertahap. Selain itu, disarankan Indonesia fokus pada komoditas yang memiliki daya saing di pasar EAEU yaitu sektor animal; vegetable; foodstuffs; plastics/ rubber, raw hides; woods; textile; stone/glass; machinery; dan transportation.
\end{abstract}

Kata Kunci: Dampak Kerja Sama, EAEU, GTAP, TCI, RSCA

\begin{abstract}
The Eurasian region is an important area for Indonesia in term of geopolitic and geostrategy. Due to the economic potential of EAEU countries, Indonesia must take advantage of it. This study aims to determine the potential competitiveness of commodities and the impact of trade cooperation between Indonesia-EAEU. Methods used in this study were Trade Complementary Index (TCI), Revealed Symetric Comparative Advantages (RSCA) and Computable General Equilibrium (CGE) model utilizing basic data of GTAP version 9 of six simulations. By using TCl method it was found that the comformity level of EAEU's export to Indonesia's import structure is higher than Indonesia's exports to the EAEU import structure. Looking at the impact of Indonesia-EAEU trade cooperation on Indonesia's economy, tariff reduction of $50 \%$ for all Indonesian products and EAEU is the best policy alternative for Indonesia. Therefore, It is a must to Indonesia to explore the possibility of cooperation with EAEU with a 50\% elimination scheme gradually to all tariff lines. Indonesia should also focus on commodities which have competitiveness in EAEU market i.e. animal; vegetable; foodstuffs; plastics/rubber, raw hides; woods; textile; stone/glass; machinery; and transportation.
\end{abstract}

Keywords: Cooperation Impact, EAEU, GTAP, TCI, RSCA

JEL Clasification: F130, F150, F170 


\section{PENDAHULUAN}

Secara geografis, Eurasia merupakan perpaduan dari dua wilayah yaitu Eropa dan Asia, dimana sekitar $75 \%$ populasi dunia, $60 \%$ dari GNP dunia, dan $75 \%$ energi di dunia berada di Eurasia (Brzezinski, 1997). Kawasan Asia Tengah menjadi kawasan dimana terdapat persaingan beberapa negara besar seperti Rusia, Amerika Serikat dan RRC (Dugis, 2015). Eurasia dianggap sebagai pusat perdagangan internasional karena merupakan jalur perdagangan yang menghubungkan Asia dengan Eropa. Kawasan Eurasia merupakan wilayah yang penting secara geopolitik dan geostrategi.

Pada tahun 1991, negara Union of Soviet Socialist Republics (USSR) atau kita kenal dengan Uni Soviet pecah menjadi 15 negara, yaitu Armenia, Azerbaijan, Byelorusia, Estonia, Georgia, Kazakhstan, Kirgizstan, Latvia, Lituania, Moldavia, Rusia, Tajikistan, Turkmenistan, Ukraina dan Uzbekistan (BPPK, Kemenlu, 2016). 15 negaranegara bekas Uni Soviet umumnya dibagi ke dalam lima kelompok, tiap-tiap wilayah memiliki ciri khas masingmasing, tidak hanya berdasarkan ciri geografis dan budaya saja, tetapi juga sejarah wilayah. Lima kelompok tersebut antara lain Negara-negara Baltik (Estonia, Latvia dan Lituania), Eropa Timur (Belarus, Moldova dan Ukraina), Kaukus Selatan (Armenia, Azerbaijan dan Georgia), Asia Tengah (Kazakhstan, Kirgizstan, Tajikistan, Turkmenistan dan Uzbekistan) dan Rusia (Yilmaz, 2017).

Selanjutnya berdasarkan custom union negara Rusia, Belarusia dan Kazakhstan menginisiasi pembentukan Eurasian Economic Union (EAEU) pada tahun 2014. EAEU ini dibentuk oleh Rusia sebagai blok tandingan Uni Eropa. Rusia memiliki kepentingan dalam pembentukan EAEU mengingat negara-negara ini merupakan pemasok gas alam utama di negara Uni Eropa (Dewi, 2011).

Rusia dan beberapa Negara pecahan Uni Soviet ini yang tergabung dalam EAEU merupakan kawasan yang dinamis dan potensial untuk dikembangkan dalam hubungan dengan Indonesia, karena memiliki kekayaan sumberdaya alam yang besar. Rusia masuk dalam negara potensial untuk pengembangan ekspor (untapped market) (Sabaruddin, 2016).

Secara geografis kawasan ini merupakan kawasan yang sangat strategis, karena merupakan jendela 
dunia timur (Timur Tengah) dan barat (Eropa) (Habova, 2016). Namun demikian Asia Tengah memiliki deposit yang besar di bidang minyak dan gas bumi serta sumber daya alam lainnya sehingga potensi unggulannya adalah minyak, gas bumi serta sumber daya alam lainnya (BPPK, Kemenlu, 2016).

Pemikiran-pemikiran kaum Statis secara resmi telah diadopsi menjadi kebijakan politik luar negeri Rusia. Konsep Keamanan Nasional 1997, misalnya, mengidentifikasi Rusia sebagai "influential European dan Asian power". Konsep ini merekomendasikan bahwa Rusia memelihara jarak yang sama (equal distance) dalam hubungan dengan aktor-aktor ekonomi dan politik di Asia dan Eropa (Bakry, 2017).

Pertimbangan lainnya adalah tergabungnya Rusia dan beberapa Negara pecahan Uni Soviet lainnya, yaitu Kazakhstan, Kirgizstan, Belarusia dan Armenia dalam Eurasian Economic Union (EAEU) merupakan potensi pasar yang besar. Hal ini membuka peluang bagi Indonesia untuk meningkatkan ekspor ke negara EAEU, walaupun jumlah populasi negara EAEU relatif lebih kecil (182,7 juta jiwa) dibandingkan dengan Indonesia (257,6 Juta jiwa), namun GDP dan GDP perkapita negara-negara EAEU relatif lebih besar dibandingkan

Indonesia

(eurasiancommission.org, 2017).

Bagi Rusia, keamanan energi berarti keamanan permintaan pada harga yang wajar. Untuk mencapai keamanan energinya, Rusia mulai melakukan strategi diversifikasi pasar sehingga tidak hanya tergantung pada Eropa (Satitah, 2016).

Rusia sebagai negara salah satu negara yang dominan di kawasan Eurasia dihadapkan pada pilihan apakah menjadi pusat peradaban dan kekuatan ideologis sesuai keunikannya atau berintegrasi dengan salah satu pusat kekuatan yang telah ada dan kehilangan identitasnya. Jika Rusia memilih independen berdasarkan sejarah dan budayanya, Rusia akan mengembangkan dan mengimplementasikan sejumlah kebijakan sesuai sumber daya yang dimilikinya di Eurasia (Hutabarat, 2017).

Secara teori, ukuran pasar atau ekonomi (market size) diukur dengan GDP dan populasi (Walsh, 2006). Tingginya GDP negara eksportir secara positif berhubungan dengan kemampuan negara tersebut untuk mengekspor lebih banyak barang dan jasa. Sedangkan tingginya GDP importir 
menunjukkan pasar bagi barang dan jasa. GDP per kapita lebih menggambarkan daya beli (purchasing power negara eksportir dan importir) (Walsh, 2006). Selain market size dan GDP, komplementaritas dan daya saing produk juga dapat menjadi pertimbangan suatu negara untuk masuk ke pasar negara lain.

Bagi Indonesia pembukaan akses pasar ke negara non tradisional seperti negara Eurasia akan sangat bermanfaat mengingat kondisi negara-negara tujuan tradisional Indonesia yang masih belum stabil. Dari segi politik, Kebijakan luar negeri Rusia di Asia Tengah dipengaruhi oleh tujuan untuk memperluas pengaruh di negara-negara eksSoviet. Di kawasan laut Kaspia ini, Rusia menginginkan adanya hubungan khusus dengan posisinya adalah sebagai negara pemimpin. Kebijakan Rusia terhadap near abroad semakin terlihat sejak masa pemerintahan Vladimir Putin menjadikan negara eksSoviet sebagai wilayah prioritas dalam kebijakan luar negeri (Siburian, 2016).

Melihat potensi yang dimiliki oleh negara-negara yang tergabung dalam EAEU, Indonesia diharapkan dapat memanfaatkan peluang yang ada. Pasar yang besar akan dapat menambah daya saing produk Indonesia dibandingkan negara lain. Saat ini negara yang telah mengadakan kerjasama dengan EAEU adalah Vietnam, sementara India, Singapura dan Iran dalam tahap penjajakan.

Itakura (2014) menggunakan model CGE dinamis untuk melihat potensi efek perekonomian dari liberalisasi dan peningkatan fasilitasi dan konektivitas pada perdagangan barang dan jasa diantara anggota ASEAN. Hasil simulasi menunjukkan pengurangan hambatan perdagangan dapat memberikan dampak positif terhadap kesejahteraan ekonomi. Penelitian lainnya dari Itakura, Fukunaga \& Isono (2013) juga menggunakan simulasi CGE untuk mengevaluasi dampak ekonomi dari aksesi Hong Kong ke ASEAN-China FTA (HK-ACFTA), dengan skenario penghapusan tarif, logistik dan pengurangan hambatan perdagangan. Penelitian tersebut memperoleh hasil bahwa semua negara yang tergabung dalam AC-FTA termasuk Hong Kong akan mendapatkan keuntungan dari aksesi tersebut dan terjadi peningkatan PDB riil dan kesejahteraan ekonomi.

Secara teori, sejalan dengan analisis statik mengenai manfaat 
perdagangan, adanya FTA mendorong berkurangnya hambatan tarif (tariffbarrier) maupun hambatan non tarif sehingga biaya transaksi dalam perdagangan akan turun. Berdasarkan teori perdagangan internasional, perdagangan internasional seharusnya akan meningkatkan kesejahteraan negara-negara yang melakukan perdagangan bebas, karena melalui perdagangan bebas akan terjadi peningkatan efisiensi penggunaan sumberdaya domestik dan akses pasar ke negara lain (Stephenson, 1994).

Adanya perdagangan antar negara ini akan mempengaruhi variabel-variabel mikro selanjutnya berdampak pada variabel-variabel makro ekonomi. Negara akan berspesialisasi sesuai dengan keunggulan komparatif sehingga kinerja ekspor akan meningkat. Proses ini menuju ke efisiensi alokasi sumberdaya dan peningkatan GDP.

Terkait dengan hal tersebut, permasalahan yang ingin dijawab dalam penelitian ini adalah bagaimana potensi kerja sama perdagangan antara Indonesia dengan negara yang tergabung dalam Eurasian Economic Union (EAEU) serta bagaimana dampaknya bagi Indonesia. Terkait dengan hal tersebut, tulisan ini mencoba untuk mengetahui potensi serta dampak yang terjadi apabila Indonesia melakukan kerja sama perdagangan dengan EAEU.

\section{METODE}

Untuk menjawab tujuan penelitian dan mengetahui potensi atau daya saing produk, penelitian ini menggunakan indeksasi perdagangan untuk mengetahui daya saing komoditi Indonesia dan EAEU. Beberapa literatur menggunakan beberapa tehnik untuk mengukur kelemahan dan keunggulan perdagangan suatu negara. Salah satu yang paling banyak digunakan adalah Revelaed Comparative Advantage (RCA) yang dikembangkan oleh Balassa (1965). Indeks RCA Balassa pada dasarnya mengukur pangsa (share) ekspor suatu negara yang dinormalkan dengan ekspor pada industri atau produk yang sama dalam satu kelompok negara (Anggoro \& Widyatutik, 2016). Formula RCA Balassa dimodifikasi sedemikian sehingga indeks tersebut simetris pada batas nilai satu dengan menggunakan formula berikut ini:

$$
R S C A=\frac{R C A-1}{R C A+1}
$$


Dengan formula tersebut nilai indeks RCA yang lebih dari satu akan memiliki indeks RSCA bernilai positif, sedangkan RCA yang bernilai kurang dari satu akan memiliki indeks RSCA negatif. Untuk mengetahui dampak dari kerja sama perdagangan antar kedua negara digunakan CGE model yang dengan data dasar GTAP versi 9. Hasil dari perkiraan dampak kerja sama dapat digunakan untuk menilai potensi dari suatu kerja sama perdagangan. Selain itu data sekunder yang lain diperoleh melalui data Badan Pusat Statistik (data ekspor impor Indonesia dengan negara anggota EAEU) dan Trademap (untuk mengetahui ekspor impor 6 digit dari dunia). Sementara itu, data-data terkait variabel makroekonomi bersumber dari Bank Indonesia dan UNCTAD. Data tarif EAEU bersumber dari Eurasia Economic Comission (2017). Dalam kajian ini akan dilakukan 6 (enam) skenario simulasi, untuk mengetahui dampak yang akan terjadi apabila kerja sama perdagangan antara Indonesia dan EAEU dilaksanakan. Skenario simulasi tersebut antara lain:

- Sim 1 Penurunan tarif sebesar $50 \%$ untuk produk unggulan Indonesia dan EAEU.
- Sim 2 Penurunan tarif menjadi $0 \%$ untuk produk unggulan Indonesia dan EAEU.

- Sim 3 Penurunan tarif sebesar $50 \%$ untuk seluruh produk Indonesia dan EAEU.

- Sim 4 Penurunan tarif sebesar $80 \%$ untuk seluruh produk Indonesia dan EAEU.

- Sim 5 Penurunan tarif sebesar $90 \%$ untuk seluruh produk Indonesia dan EAEU.

- Sim 6 Penurunan tarif menjadi 0\% untuk seluruh produk Indonesia dan EAEU.

Produk unggulan yang ditentukan adalah dari hasil perhitungan daya saing (RSCA) dan tarif yang masih relatif tinggi baik di Indonesia maupun EAEU. Untuk Indonesia sektor komoditi yang memiliki daya saing dan masih dikenakan tarif tinggi di EAEU adalah Vegetable oils and fats, Leather products, Wood products, Metal products, Manufactures nec dan Wearing apparel. Sedangkan sektor komoditi EAEU yang memiliki daya saing dan masih dikenakan tarif tinggi di Indonesia adalah Chemical, rubber, plastic prods, Ferrous metals, Transport equipment nec, Raw milk, Food products nec dan Vegetables, fruit, nuts. 
Data sekunder utama bersumber dari database GTAP versi 9 yang diterbitkan tahun 2015. GTAP versi 9 terdapat pembaharuan dalam hal data yang menggunakan data referensi tahun 2004, 2007 dan 2011 dan terdiri dari 140 region dan 57 sektor. Terdapat pembaharuan dari GTAP versi 9 yaitu update data referensi 3 tahun yaitu tahun 2004, 2007 dan 2011, total region menjadi 140 region dan 57 sektor. Disamping itu terdapat Data makro ekonomi yang baru yaitu 2004, 2007, and 2011, update data perdagangan merchandise bilateral baru yaitu untuk 2011, update data proteksi baru untuk tahun 2007 dan 2011, update data perdagangan bilateral time series baru dari 1995-2013 serta perbaikan dalam data perdagangan bilateral jasa untuk tahun 2004, 2007, and 2011.

Menurut Walmsley et al. (2012) data IO GTAP Versi 8, bervariasi antar negara. $\quad$ IO pertanian diperoleh dari FAO, income taxes bersumber dari IMF, data agricultural domestic support berasal dari kontribusi Hsin Huang untuk negara-negara anggota OECD dan Hans Jensen untuk EU-27 countries, data ekonomi makro diperoleh dari World Bank, data perdagangan bersumber dari COMTRADE database, USITC, data perdagangan jasa berasal dari OECD and IMF, data proteksi bersumber dari CEPII dan ITC-Geneva.

\section{HASIL DAN PEMBAHASAN}

\section{Gambaran Perdagangan Indonesia-EAEU}

Tabel 1. Ekspor Non Migas Indonesia Ke Negara EAEU

\begin{tabular}{|c|c|c|c|c|c|c|c|c|c|c|c|}
\hline \multirow[b]{2}{*}{ No } & \multirow[b]{2}{*}{ Negara Tujuan } & \multicolumn{7}{|c|}{ Nilai: USD Juta } & \multirow{2}{*}{$\begin{array}{l}\text { Perub(\%) } \\
\text { 2016/2017 }\end{array}$} & \multirow{2}{*}{$\begin{array}{l}\text { Trend(\%) } \\
\text { 2012-2016 }\end{array}$} & \multirow{2}{*}{$\begin{array}{c}\text { Share(\%) } \\
2016\end{array}$} \\
\hline & & 2012 & 2013 & 2014 & 2015 & 2016 & $\begin{array}{c}\text { Jan-Mar } \\
2016\end{array}$ & $\begin{array}{c}\text { Jan-Mar } \\
2017\end{array}$ & & & \\
\hline & Eurasia & 885.8 & 945.4 & 1069.8 & 1001.2 & 1275.3 & 178.4 & 341.8 & 91.6 & 8.2 & 100.0 \\
\hline 1 & Federasi Rusia & 867.3 & 930.3 & 1052.9 & 993.7 & 1261.6 & 176.9 & 338.2 & 91.1 & 8.5 & 98.9 \\
\hline 2 & Kazakhstan & 8.4 & 6.7 & 8.3 & 3.2 & 7.2 & 0.7 & 2.2 & 212.1 & -10 & 0.6 \\
\hline 3 & Belarusia & 3.8 & 4.0 & 3.9 & 0.5 & 2.9 & 0.1 & 0.4 & 295.7 & -22.8 & 0.2 \\
\hline 4 & Armenia & 3.5 & 3.7 & 3.8 & 2.7 & 2.2 & 0.5 & 0.8 & 47.1 & -11.7 & 0.2 \\
\hline 5 & Kyrgyzstan & 2.8 & 0.9 & 0.9 & 1.0 & 1.5 & 0.2 & 0.3 & 62.4 & -10 & 0.1 \\
\hline
\end{tabular}

Sumber: BPS (2018), diolah

Kinerja neraca perdagangan non migas Indonesia dengan EAEU periode 2012-2015 menunjukkan posisi defisit, meskipun pada tahun 2016 Indonesia mengalami surplus perdagangan dengan EAEU. Namun pada Januari- 
Maret 2017, Indonesia kembali mencatat defisit neraca perdagangan sebesar USD 23,6 juta. Neraca perdagangan yang defisit ini ditunjang dengan tren pertumbuhan total perdagangan Indonesia dan EAEU yang menurun sebesar $12,7 \%$ per tahun selama periode 2012-2016.

Total perdagangan Indonesia dengan EAEU di tahun 2016 mencapai USD 2,3 miliar dimana keseluruhan perdagangan di tahun tersebut merupakan kontribusi dari sektor non migas. Pada Januari-Maret 2017 perdagangan Indonesia dengan EAEU mencapai USD 707,3 juta atau naik $77,5 \%$ dibandingkan periode yang sama tahun sebelumnya.

Rusia merupakan negara tujuan utama ekspor non-migas Indonesia ke kawasan EAEU dengan pangsa mencapai $98,9 \%$. Negara lainnya yang meliputi Kazakhstan, Belarusia, Armenia dan Kyrgyzstan memiliki kontribusi yang minim bagi ekspor Indonesia. Terlebih lagi, tren ekspor ke negara-negara tersebut periode 20122016 cenderung mengalami penurunan.

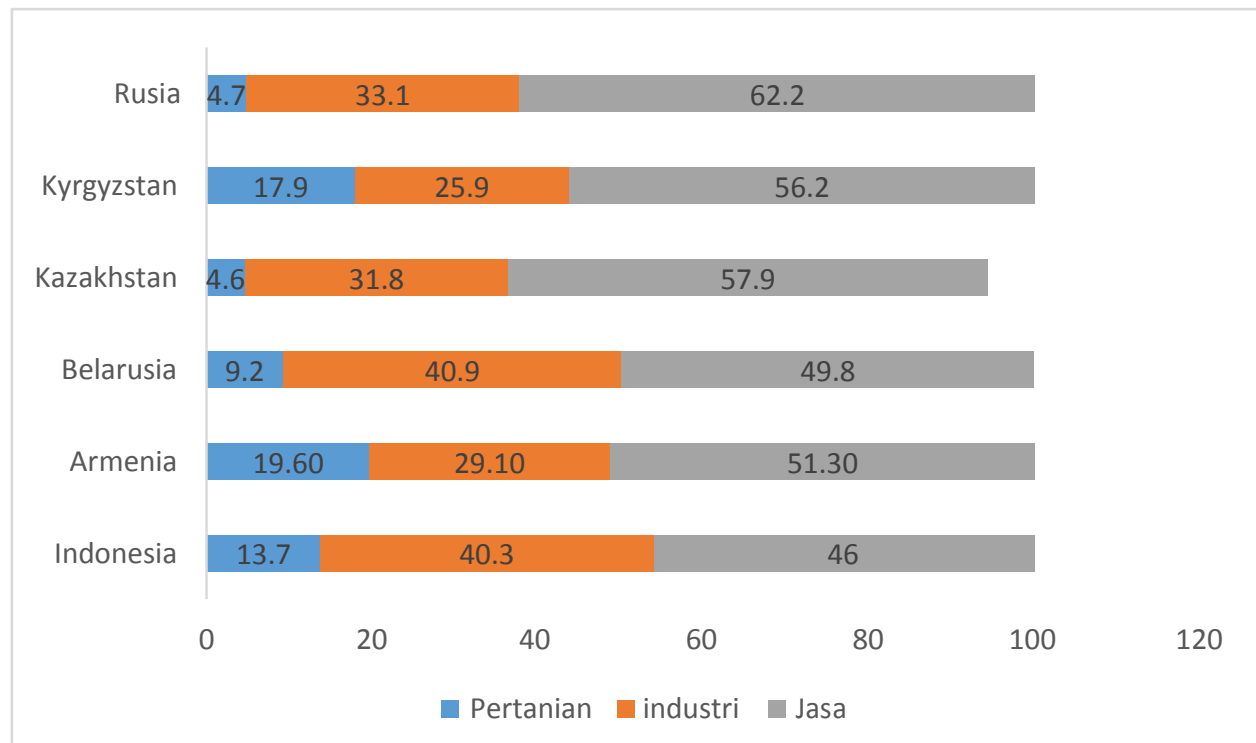

\section{Gambar 1. Komposisi GDP Indonesia dan Negara anggota EAEU Tahun 2016 (\%)}

Sumber: CIA factbook (2017), diolah

Perekonomian negara EAEU menjadi penopang terbesar dalam GDP secara umum ditopang oleh sektor baik itu untuk Indonesia maupun negara pertanian, Industri dan jasa yang EAEU. Sedangkan untuk sektor berbeda-beda untuk masing-masing pertanian, Kyrgyzstan dan Armenia negara. Sebagian besar sektor jasa memberikan komposisi $17,9 \%$ dan 
19,6\%. Sementara, walaupun sektor jasa dan industri manufaktur berperan penting dalam ekonomi Indonesia, sektor pertanian tetap memberikan kontribusi yang cukup signifikan. Peran masing-masing sektor dalam ekonomi Indonesia yaitu jasa $46 \%$, industri $40,3 \%$ dan pertanian $13,7 \%$.

Negara asal impor Indonesia dari kawasan EAEU didominasi oleh Rusia dengan pangsa $82,6 \%$, diikuti oleh Belarus (15,9\%) dan Kazakhstan $(1,5 \%)$. Meskipun tren impor non migas Indonesia dari Rusia periode 2012-2016 menurun 20,6\% per tahun, namun impor non-migas tahun 2016 meningkat $83,9 \%$ YoY. Hal ini mengindikasikan penetrasi produk ekspor Rusia makin kuat di pasar Indonesia.

\section{Tabel 2. Impor Non Migas Indonesia Dari Negara EAEU}

\begin{tabular}{|c|c|c|c|c|c|c|c|c|c|c|c|}
\hline \multirow[b]{2}{*}{ No } & \multirow[b]{2}{*}{ Negara Tujuan } & \multicolumn{7}{|c|}{ Nilai: USD Juta } & \multirow{2}{*}{$\begin{array}{l}\text { Perub(\%) } \\
\text { 2016/2017 }\end{array}$} & \multirow{2}{*}{$\begin{array}{l}\text { Trend(\%) } \\
\text { 2012-2016 }\end{array}$} & \multirow{2}{*}{$\begin{array}{c}\text { Share(\%) } \\
2016\end{array}$} \\
\hline & & 2012 & 2013 & 2014 & 2015 & 2016 & $\begin{array}{c}\text { Jan-Mar } \\
2016\end{array}$ & $\begin{array}{c}\text { Jan-Mar } \\
2017\end{array}$ & & & \\
\hline & Eurasia & $1,920.5$ & $2,218.3$ & $1,398.9$ & $1,129.4$ & $1,029.7$ & 220.1 & 365.4 & 66 & -17.5 & 100.0 \\
\hline 1 & Federasi Rusia & $1,777.4$ & $2,070.1$ & $1,183.2$ & 903.9 & 850.6 & 168.0 & 309.0 & 83.9 & -20.6 & 82.6 \\
\hline 2 & Belarusia & 86.9 & 129.8 & 186.3 & 210.9 & 163.6 & 47.9 & 44.2 & -7.8 & 19.2 & 15.9 \\
\hline 3 & Kazakhstan & 54.8 & 16.9 & 28.2 & 13.8 & 14.9 & 3.8 & 11.9 & 214.8 & -24.4 & 1.5 \\
\hline 4 & Kyrgyzstan & 1.4 & 1.3 & 0.6 & 0.7 & 0 & 0 & 0 & 0 & 0 & 0.0 \\
\hline 5 & Armenia & 0 & 0 & 0.4 & $\underline{0}$ & 0 & 0 & 0 & 0 & 0 & 0.0 \\
\hline
\end{tabular}

Sumber: BPS (2018), diolah

Ekspor non migas Indonesia ke EAEU selama 2012-2016 menunjukkan peningkatan rata-rata sebesar $8,2 \%$ per tahun. Pada tahun 2016 ekspor non migas Indonesia ke EAEU mencapai USD 1,3 miliar dengan pangsa $1,0 \%$ terhadap total ekspor non migas Indonesia ke dunia. Pada periode Januari-Maret 2017, ekspor non migas Indonesia ke EAEU mencapai USD 341,8 juta atau mengalami peningkatan signifikan hingga mencapai 91,6\% YoY. Peningkatan tersebut merupakan indikasi positif untuk kelanjutan peningkatan ekspor Indonesia ke EAEU. Produk utama ekspor Indonesia ke Eurasia adalah CPO dan turunannya, Mesin, Kopi, Kakao, Karet dan produk turunannya, Teh dan Alas Kaki.

Sementara itu, kinerja impor nonmigas Indonesia dari EAEU selama 2012-2016 menunjukkan penurunan rata-rata sebesar $17,5 \%$ per tahun. Pada periode Januari-Maret 2017, impor non migas Indonesia dari EAEU mencapai USD 365,4 juta atau mengalami penurunan $66,0 \%$ YoY, dimana produk impor non migas yang 
paling banyak dibutuhkan Indonesia dari EAEU adalah potassium chloride (HS 3104.20), produk besi/baja setengah jadi (HS 7207.12), komponen pesawat terbang (HS 8803.30), alumunium (HS 7601.20) dan asbes (HS 2524.90).

\section{Analisis Potensi dan Daya Saing} Komoditi

Trade Complementary Index (TCl) antara Indonesia dan EAEU dapat memberikan informasi yang berguna bagi prospek perdagangan intraregional. Hal ini menunjukkan tingkat kecocokan struktur impor dan ekspor suatu negara. TCl merupakan salah satu alat analisis dalam mempertimbangkan pembentukan kerja sama perdagangan dengan negara mitra. Sejak tahun 2011, tingkat kesesuaian ekspor EAEU terhadap struktur impor Indonesia lebih tinggi dibandingkan ekspor Indonesia terhadap struktur impor EAEU (Gambar 2). Tingkat kesesuaian ekspor EAEU terhadap struktur impor Indonesia pada tahun 2015 sebesar 30,07\%, lebih tinggi dibandingkan tingkat kesesuaian ekspor Indonesia terhadap struktur impor EAEU yang sebesar $26,86 \%$. Hal ini menunjukkan EAEU memiliki kemampuan yang lebih baik untuk memenuhi permintaan impor Indonesia dibandingkan Indonesia memenuhi permintaan impor EAEU.

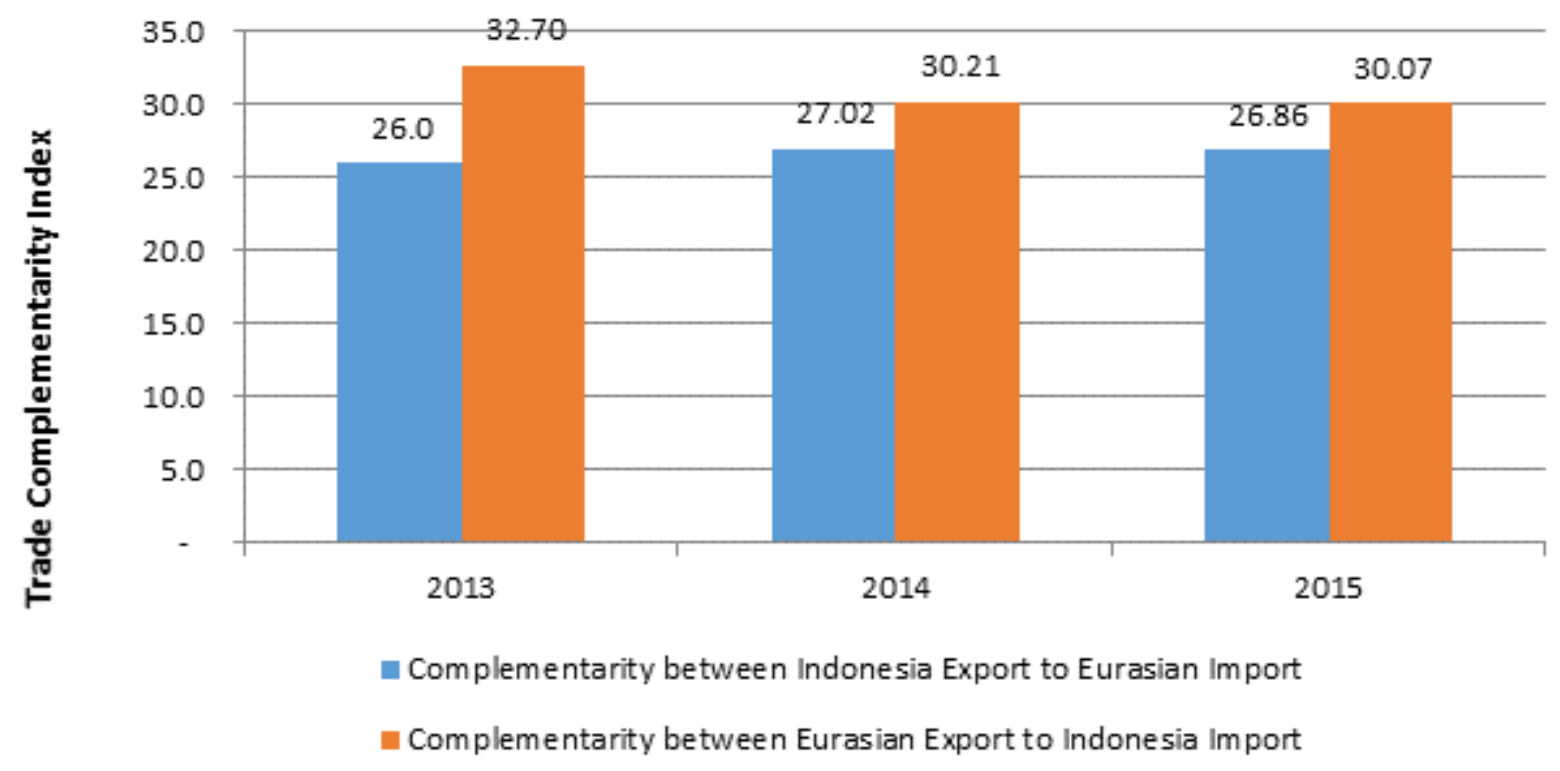

\section{Gambar 2. TCI Indonesia-EAEU}

Sumber: Trademap (2017), diolah 
Revealed Symmetric Comparative Advantage (RSCA) bilateral antara Indonesia dan EAEU menunjukkan bahwa Indonesia memiliki daya saing secara relatif di pasar EAEU pada sektor animal; vegetable; foodstuffs; chemical; plastics/ rubber; raw hides; woods; textile; stone/glass; machinery; dan transportation, sedangkan EAEU memiliki daya saing secara relatif di pasar Indonesia untuk mineral products; chemical; metals; dan miscellaneous. Berdasarkan kinerja perdagangan saat ini, beberapa sektor vegetables product menjadi produk yang dominan di ekspor Indonesia ke EAEU, seperti Palm oil dengan share $27,9 \%$, coffee $(3,7 \%)$, kopra $(2,8 \%)$. Sektor machinery juga menjadi produk dengan share terbesar kedua dengan share sebesar $20,7 \%$.

Tabel 3. Bilateral Revealed Symmetric Comparative Advantage

\begin{tabular}{lrrrr}
\hline & \multicolumn{2}{c}{$\begin{array}{c}\text { RSCA Indonesia } \\
\text { Selative to }\end{array}$} & \multicolumn{2}{c}{$\begin{array}{c}\text { RSCA Eurasian } \\
\text { Relative to }\end{array}$} \\
\cline { 2 - 5 } & Eurasian & Global & Indonesia & Global \\
\hline animal and animal product & 0.10 & 0.05 & -0.10 & -0.05 \\
vegetable products & 0.63 & 0.63 & -0.63 & 0.00 \\
foodstuffs & 0.44 & 0.12 & -0.44 & -0.34 \\
mineral products & -0.37 & 0.34 & 0.37 & 0.64 \\
chemical and allied industries & 0.07 & -0.16 & -0.07 & -0.23 \\
plastics/rubber & 0.51 & 0.11 & -0.51 & -0.42 \\
raw hides, skins, leather and furs & 0.48 & -0.36 & -0.48 & -0.72 \\
wood and wooden products & 0.32 & 0.46 & -0.32 & 0.17 \\
textile & 0.86 & 0.27 & -0.86 & -0.77 \\
footwear/headgear & 0.94 & 0.57 & -0.94 & -0.81 \\
stone/glass & 0.17 & -0.01 & -0.17 & -0.18 \\
metals & -0.19 & -0.34 & 0.19 & -0.17 \\
machinery/electrical & 0.56 & -0.45 & -0.56 & -0.81 \\
transportation & 0.41 & -0.48 & -0.41 & -0.74 \\
miscellaneous & -0.73 & -0.51 & 0.73 & 0.35 \\
Maximum Value of RSCA & Complanatory Note & & & \\
Minimum Value of RSCA & 1.00 & & & \\
Critical Point & -1.00 & & & \\
\hline
\end{tabular}

Sumber: Trademap (2017), diolah 


\section{Analisis Dampak Ditinjau dari Makro}

\section{Ekonomi}

Kajian akan melakukan enam skenario simulasi, untuk mengetahui dampak yang akan terjadi apabila terjadi kerja sama perdagangan antara Indonesia-EAEU. Berdasarkan simulasi akan dianalisis dampaknya terhadap ekonomi makro dan sektoral Indonesia dan EAEU. Dalam perspektif makroekonomi, analisis prediktif sebagai konsekuensi terbentuknya skema kerja sama perdagangan akan memengaruhi magnitude variabelvariabel kunci makroekonomi seperti tingkat kesejahteraan (menggunakan proksi Equivalent Variation) dan output di level nasional (menggunakan proksi GDP riil). Dari sisi pengeluaran, komponen GDP yang dianalisis adalah pengeluaran investasi, konsumsi swasta dan pemerintah serta kinerja perdagangan yang ditunjukkan melalui variabel neraca perdagangan (DTBAL). Komponen makroekonomi yang juga dianalisis adalah tingkat inflasi yang dilihat dari GDP deflator. Selain dampak terhadap indikator makroekonomi, kajian ini juga akan menganalisis dampak kerja sama perdagangan terhadap sektor. Indikator sektoral yang menjadi fokus bahasan adalah output, harga output, ekspor, impor, dan kesempatan kerja.

Tabel 4. Hasil Simulasi GTAP

\begin{tabular}{lrrrrrr}
\hline \multirow{2}{*}{ Indikator Makro } & \multicolumn{2}{c}{ Sim 1 } & \multicolumn{2}{c}{ Sim 2 } & \multicolumn{2}{c}{ Sim 3 } \\
& Indonesia & EAEU & Indonesia & EAEU & Indonesia & \multicolumn{1}{c}{ EAEU } \\
\hline Kesejahteraan (Juta USD) & 25.5 & 22.6 & 40.0 & 43.8 & 40.2 & 27.7 \\
GDP Riil (\%) & 0.0007 & -0.0008 & -0.0004 & -0.0022 & 0.0010 & -0.0006 \\
Konsumsi (\%) & 0.015 & 0.009 & 0.030 & 0.020 & 0.025 & 0.009 \\
Investasi (\%) & 0.020 & 0.013 & 0.045 & 0.030 & 0.025 & 0.016 \\
Neraca Perdagangan (Juta USD) & -35.9 & -39.1 & -84.6 & -91.8 & -43.7 & -51.5 \\
Ekspor (\%) & 0.037 & 0.010 & 0.090 & 0.024 & 0.042 & 0.013 \\
Impor (\%) & 0.066 & 0.036 & 0.157 & 0.084 & 0.082 & 0.043 \\
\hline \multicolumn{1}{c}{ Indikator Makro } & Sim 4 & \multicolumn{2}{c}{ Sim 5} & Sim 6 \\
& Indonesia & EAEU & Indonesia & EAEU & Indonesia & EAEU \\
\hline Kesejahteraan (Juta USD) & 60.912 & 42.491 & 66.95 & 46.884 & 72.457 & 50.893 \\
GDP Riil (\%) & 0.00082 & -0.00131 & 0.00058 & -0.00161 & 0.00024 & -0.00196 \\
Konsumsi (\%) & 0.042 & 0.016 & 0.047 & 0.018 & 0.0533 & 0.021 \\
Investasi (\%) & 0.043 & 0.028 & 0.05 & 0.032 & 0.0566 & 0.0367 \\
Neraca Perdagangan (Juta USD) & -76.81 & -90.042 & -89.3 & -104.434 & -102.603 & -119.685 \\
Ekspor (\%) & 0.076 & 0.023 & 0.088 & 0.027 & 0.102 & 0.0306 \\
Impor (\%) & 0.144 & 0.075 & 0.168 & 0.087 & 0.1926 & 0.0996 \\
\hline
\end{tabular}


Berdasarkan keseluruhan simulasi dampak dari skema kerja sama perdagangan Indonesia dan EAEU meningkatkan kesejahteraan Indonesia dan EAEU. Tingkat kesejahteraan menggunakan proksi Equivalent Variation. Equivalent Variation mengukur kesejahteraan dengan menghitung surplus produsen, konsumen dan pemerintah. Surplus dari sisi produksi dimungkinkan karena penurunan hambatan perdagangan berupa penurunan tarif maupun liberalisasi perdagangan (zero tariff) akan memberikan insentif bagi produsen untuk meningkatkan output. Peningkatan kesejahteraan terjadi karena ada peningkatan surplus produsen.

Peningkatan kesejahteraan tertinggi Indonesia terjadi pada $\operatorname{Sim} 6$, ketika disimulasikan terjadi liberalisasi perdagangan penuh dengan penurunan tarif impor menjadi 0 . Kesejahteraan yang lebih tinggi pada Sim 6 ini lebih banyak disebabkan karena peningkatan surplus konsumen. Liberalisasi perdagangan mendorong peningkatan impor lebih besar sehingga konsumen memiliki pilihan lebih banyak dan memperoleh harga impor yang relatif lebih murah. Hasil ini konsisten dengan dampak peningkatan konsumsi baik konsumsi swasta maupun pemerintah yang lebih tinggi pada $\operatorname{Sim} 6$ ini. Peningkatan kesejahteraan Indonesia terendah terjadi pada Sim 1 ketika penurunan tarif hanya sebesar $50 \%$ pada produk unggulan yaitu sebesar USD 25,519.

Dampak skema kerja sama Indonesia-EAEU terhadap persentase perubahan GDP riil untuk Indonesia, hanya Sim 2 (Liberalisasi Perdagangan Penuh untuk Produk Unggulan dengan Penurunan Tarif Impor Menjadi 0\%) yang berdampak pada penurunan GDP riil Indonesia walaupun relatif kecil yaitu sebesar 0.0004. Hasil simulasi ini mengimplikasikan bahwa adanya liberalisasi pada komoditas unggulan Indonesia maupun Eurasia tidak akan serta merta mendorong peningkatan GDP riil.

Eliminasi tarif yang dilakukan melalui Sim 3 akan mendorong peningkatan output bagi Indonesia di beberapa produk antara lain: vegetable oil (vol); wearring apparel (wap); leather products (lea); wood products (lum); metal products (fmp); manufactures nec (omf); textile (tex); oilseed (osd); forrest (frs); mineral product nec ( $\mathrm{nmm}) ;$ dan 
meat product nec (omt) dan dua sektor jasa yaitu constructions (cns) dan distributions/trade (trd).

Sejalan dengan teori ekonomi, dimana permintaan tenaga kerja merupakan permintaan turunan (derived demand) terhadap output, sehingga sektor-sektor yang mengalami peningkatan output pada keseluruhan simulasi, mengalami peningkatan permintaan tenaga kerja. Hasil simulasi mengindikasikan bahwa liberalisasi secara penuh relatif tidak memberikan insentif dan strategi jangka panjang bagi industri untuk meningkatkan produktivitas adalah melalui efisiensi produksi maupun adopsi teknologi. Adopsi teknologi ini diperlukan guna meningkatkan daya saing produk Indonesia, khususnya di pasar EAEU. Alih teknologi ini akan memberikan benefit sehingga akan memberikan output produksi yang optimal bagi industri. Saat ini industri relatif "terlena" dengan proteksi yang diberikan pemerintah. Kebijakan pengenaan tarif ini dikritisi sebagai proteksi terhadap industri domestik yang tidak efisien dari persaingan internasional (Feenstra, 2004). Kelima simulasi lainnya berdampak pada peningkatan GDP riil Indonesia.
Variabel lainnya yang menjadi fokus dalam tataran makro adalah indikator makro neraca perdagangan. Preseden negatif kinerja perdagangan ditunjukkan dengan nilai yang negatif neraca perdagangan pada keseluruhan simulasi baik Indonesia maupun EAEU. Defisit neraca perdagangan Indonesia yang paling tinggi terjadi pada Sim6 yaitu ketika liberalisasi perdagangan penuh. Dengan dibukanya hambatan perdagangan pada seluruh sektor berpotensi meningkatkan impor lebih tinggi dibandingkan dengan peningkatan ekspor sehingga menyebabkan defisit neraca perdagangan sebesar USD 102,603 juta. Demikian juga untuk EAEU, seperti halnya Indonesia, defisit neraca perdagangan tertinggi juga pada $\operatorname{Sim} 6$, yaitu sebesar USD 119,685 juta. Apabila defisit neraca perdagangan Indonesia dibandingkan dengan EAEU, maka defisit neraca perdagangan Indonesia relatif lebih rendah dibandingkan dengan EAEU di setiap simulasi.

Penurunan bahkan eliminasi tarif dengan adanya skema kerjasama Indonesia dan EAEU, mendorong peningkatan konsumsi riil rumah tangga. Baik konsumsi riil rumah tangga 
Indonesia maupun EAEU mengalami peningkatan tertinggi pada Sim 6 (liberalisasi perdagangan penuh dengan penurunan tarif impor menjadi 0\%) disusul Sim 5, Sim 4, Sim 2 dan terakhir Sim 1. Besaran persentase peningkatan untuk konsumsi riil rumah tangga Indonesia berturut-turut dari yang tertinggi yaitu $0.0533 \%$ (Sim 6), $0.0470 \%$ (Sim 5), $0.0420 \%$ (Sim 4), $0.0301 \%$ (Sim 2), 0.0250\% (Sim 3) dan $0.0148 \%$ (Sim 1). Penurunan dan eliminasi tarif dari tingkat yang lebih tinggi berpengaruh terhadap besaran impor Indonesia. Selain karena relatif tingginya tarif impor Indonesia dibanding EAEU, hal ini juga mengimplikasikan bahwa respon konsumsi Indonesia terhadap barang impor dibandingkan dengan EAEU relatif lebih besar.

Skema penurunan dan eliminasi tarif secara komprehensif telah menyediakan ruang untuk peningkatan investasi. Persetujuan untuk menurunkan dan bahkan meliberalisasi perdagangan akan mendorong dunia usaha untuk menyesuaikan dengan lingkungan bisnis tanpa hambatan. Daya tarik investasi akan menjadi semakin tinggi dengan penurunan dan eliminasi tarif impor sehingga memberikan insentif bagi investor untuk meningkatkan investasinya. Baik Indonesia maupun EAEU mengalami peningkatan investasi di seluruh simulasi dimana persentase peningkatan investasi tertinggi terjadi pada Sim 6 (liberalisasi perdagangan penuh dengan penurunan tarif impor menjadi $0 \%$ ) yaitu sebesar $0.0566 \%$ untuk Indonesia dan $0.0367 \%$ untuk EAEU.

Hasil simulasi juga menunjukkan dampak terhadap ekspor impor Indonesia konsisten dengan dampak terhadap kinerja perdagangan. Persentase peningkatan impor lebih tinggi dibandingkan dengan persentase peningkatan ekspor. Kondisi ini sejalan dengan penelitian Oktaviani, Widyastutik \& Amaliah (2010) untuk kasus dampak FTA di Indonesia. Adanya persentase perubahan kenaikan impor yang lebih tinggi dari persentase ekspor, mengakibatkan dampak negatif dalam neraca perdagangan (trade balance) Indonesia Kinerja ekspor yang lebih rendah dari impor saat ini di duga dipengaruhi oleh Non Tarif Measures (NTM) suatu negara. Saat ini banyak negara yang memiliki NTM yang banyak untuk melindungi daya saing produk mereka, 
di saat tarif bea masuk sudah semakin liberal.

Berdasarkan hasil perhitungan, peningkatan impor dan ekspor tertinggi terjadi pada Sim 6, dimana disimulasikan liberalisasi perdagangan penuh dengan penurunan impor menjadi $0 \%$. Ketika liberalisasi perdagangan secara penuh diberlakukan hanya pada produk unggulan (Sim 2), kenaikan impor menduduki posisi kedua, selanjutnya disusul $\operatorname{Sim} 5, \operatorname{Sim} 4$, Sim 3 dan $\operatorname{Sim} 1$. Sim 1 (penurunan tarif sebesar 50\% untuk produk unggulan) dan $\operatorname{Sim} 3$ (penurunan tarif sebesar 50\% untuk seluruh produk) relatif tidak menyebabkan peningkatan laju impor seperti pada $\operatorname{Sim} 6, \operatorname{Sim} 5, \operatorname{Sim} 4$ dan Sim 2. Seperti halnya Indonesia, laju pertumbuhan impor EAEU juga lebih tinggi dibandingkan dengan laju pertumbuhan ekspor. Walaupun arahnya sama, namun besarannya relatif lebih tinggi laju pertumbuhan ekspor dan impor Indonesia dibandingkan dengan EAEU.

\section{KESIMPULAN DAN REKOMENDASI KEBIJAKAN}

Berdasarkan analisis $\mathrm{TCl}$, tingkat kesesuaian ekspor EAEU terhadap struktur impor Indonesia lebih tinggi dibandingkan ekspor Indonesia terhadap struktur impor EAEU. Tingkat kesesuaian ekspor EAEU terhadap struktur impor Indonesia pada tahun 2015 sebesar 30,22\%, lebih tinggi dibandingkan tingkat kesesuaian ekspor Indonesia terhadap struktur impor EAEU yang sebesar $26,97 \%$. Hal ini menunjukkan EAEU memiliki kemampuan yang lebih baik untuk memenuhi permintaan impor Indonesia dibandingkan Indonesia memenuhi permintaan impor EAEU. Hasil analisis RSCA bilateral antara Indonesia dan EAEU menunjukkan bahwa Indonesia memiliki daya saing secara relatif di pasar EAEU pada sektor animal; vegetable; foodstuffs; plastics/ rubber, raw hides; woods; textile; stone/glass; machinery; dan transportation, sedangkan EAEU memiliki daya saing secara relatif di pasar Indonesia untuk mineral products; chemical; metals; dan miscellaneous.

Simulasi 3 merupakan alternatif kebijakan terbaik bagi Indonesia diantara lima simulasi lainnya dengan melihat dampak kerja sama perdagangan Indonesia dan EAEU terhadap makroekonomi. Hal ini ditunjukkan dengan peningkatan GDP sebesar $\quad 0,001 \%$, kenaikan kesejahteraan USD 40,2 Juta, 
peningkatan konsumsi 0,025\%, mengakomodir kesiapan sektor di kenaikan investasi $0,025 \%$ dan defisit Indonesia.

neraca perdagangan sebesar $43,7 \%$

Keseluruhan

simulasi

(relatif lebih kecil dibandingkan simulasi

menunjukkan peningkatan impor lainnya). Namun demikian, penurunan Indonesia relatif lebih besar tarif sebesar $50 \%$ relatif pada keseluruhan kurang memberikan insentif bagi investor untuk menanamkan modalnya di Indonesia. Hal tersebut mengindikasikan bahwa kebijakan perdagangan (dalam bentuk penurunan tarif) yang tidak disertai dengan kebijakan lain tidak akan mampu meningkatkan investasi di Indonesia.

Dalam simulasi tersebut diketahui persentase peningkatan permintaan tenaga kerja tidak terdidik lebih tinggi dibandingkan tenaga kerja terdidik. Hal ini mengimplikasikan sektor-sektor yang meningkat outputnya lebih didominasi sektor yang memiliki tenaga kerja tidak terdidik seperti sektor pertanian maupun industri pengolahan.

Indonesia perlu menjajaki kemungkinan kerjasama dengan EAEU dengan menggunakan alternatif pendekatan berupa eliminasi seluruh pos tarif dengan tingkat pemotongan tarif 50\% (Sim 3). Eliminasi tarif ini dapat dilakukan secara bertahap dengan dibandingkan ekspor yang ditunjukkan dengan defisit neraca perdagangan, sehingga daya saing perlu ditingkatkan. Adopsi teknologi agar produksi efisien merupakan syarat mutlak agar Indonesia memperoleh benefit dalam kerja sama perdagangan IndonesiaEAEU.

\section{UCAPAN TERIMAKASIH}

Terima kasih kami sampaikan kepada Kepala Pusat Pengkajian Kerjasama Perdagangan Internasional atas semua masukannya, serta lbu Widyastutik dan Ibu Syarifah Amaliah selaku tenaga ahli.

\section{DAFTAR PUSTAKA}

Anggoro, R., Widyastutik. (2016). Non-Tariff Barrier and Factors that Influence The Indonesian Cocoa Export to Europe. Signifikan: Jurnal IImu Ekonomi. Vol 5 (2) October 2016.

Bakry, Umar Suryadi. (2017) Perspektif Rusia tentang Hubungan Internasional Pasca Perang Dingin. Bandung: Jurnal IImiah Hubungan Internasional Universitas Katolik Parahyangan: Vol 13. No 1 tahun 2017.

Balassa, B. (1965). Trade Liberalization and Revealed Comparative Advantage. Manchester School of Economic and Social Studies 33 99-123. 
Badan Pusat Statistik (BPS). (2018). Statistik Indonesia Tahun 2017. Jakarta Pusat: Badan Pusat Statistik.

BPPK, Kementerian Luar Negeri. (2016). Indonesia dan Asia Tengah: Sebuah Upaya Penguatan Diplomasi Ekonomi. Jakarta: Kementerian Luar Negeri.

Brzezinski, Zbigniew. (1997). A Geostrategy for Eurasia. Foreign Affairs, Vol. 76, No. 5 (Sep. - Oct., 1997), pp. $50-64$

Central Intellegency Agency (CIA). (2017). Economic overview of Rusia, Belarusia, Armenia, Kazakhstan and Kyrgyzstan. Diunduh pada Februari 2017 dari https://www.cia.gov.

Dewi, Rosita. (2011). Konflik RusiaUkraina: Rentannya Stabilitas Energi Uni Eropa. Jakarta: LIPI, Pusat Penelitian Politik.

Dugis, Vinsensio. (2015). Defining Eastern Europe. Masyarakat Budaya Politik Rusia, Eropa Timur, Asia Tengah. Surabaya: Departemen Hubungan Internasional, Fakultas IImu Sosial IImu Politik, Universitas Airlangga.

Eurasian Economic Commission. (2017). Makro Ekonomi negara - negara Eurasia. Diunduh pada Januari 2018 melalui

http://www.eurasiancommission.org.

Feenstra, R., C. (2004). Advanced Internasional Trade. Theory and Evidence. Princenton University Pers.

Habova, Antonina Ivanova. (2016). Southeast Europe In The New Geopolitical Context. IJASOSInternational E-Journal of Advances in Social Sciences, Vol.II, Issue 4, April 2016.

Hutabarat, Leonard F. (2017). Eurasianisme dan Kebijakan Luar Negeri Rusia. Bandung: Jurnal IImiah Hubungan Internasional Universitas Katolik Parahyangan. Vol 13. No 1 tahun 2017.
Itakura, K. (2014). Impact of Liberalization and Improved Connectivity and Facilitation in ASEAN. Journal of Asian Economics. Volume 35, pages 1-106 (December 2014).

Itakura, K., Fukunaga, Y., \& Ishono, I. (2013). A CGE Study of Economic Impact of Accession of Hong Kong to ASEAN-China Free Trade Agreement. ERIA Discussion Paper Series, ERIADP-2013-06.

Oktaviani, R, Widyastutik, Amaliah, S. (2010). Dampak FTA ASEAN-China terhadap Ekonomi Makro, Sektoral, Regional, dan Distribusi Pendapatan Indonesia. Jurnal IImu Pertanian Indonesia, Desember 2010, hlm. 192204.

Sabaruddin, Sulthon Sjahril. (2016). Penguatan Diplomasi Ekonomi Indonesia Mendesain Clustering Tujuan Pasar Ekspor Indonesia: Pasar Tradisional vs Pasar NonTradisional. Bandung: Jurnal IImiah Hubungan Internasional Universitas Katolik Parahyangan. Vol 12. No 1 tahun 2016

Satitah, Dinar Okti Noor. (2016). Implikasi Kerja sama Tiongkok-Rusia Terkait Upaya Menjaga Keamanan Energi Tiongkok. Surabaya: Jurnal Analisis Hubungan Internasional, Vol. 5 No. 2, Juni 2016

Siburian, Trisiska Apriani. (2016). Kepentingan Rusia Dalam Kerjasama Antar Negara negara Laut Kaspia. Riau : Jurnal Online Mahasiswa. Vol 3 No 2-Okt 2016.

Stephenson, S.M. (1994). The Uruguay Round and Its Benefit to Indonesia. Ministry of Trade, The Republic of Indonesia, Jakarta.

TradeMap. (2017). Data Ekspor dan Impor Indonesia dan Uni Eropa. Diunduh pada Januari 2016 melalui http://www.trademap.org/.

Walsh, K. (2006). Trade in Services: Does Gravity Hold? A Gravity Model Approach to Estimating Barriers to 
Services. Institute for International Integration Studies (IIIS), Discussion Paper, No 183/October 2006.

Walmsley, T.L, E. lanchovichina (Eds.) (2012). Dynamic Modeling and Applications for Global Economic
Analysis. New York, NY: Cambridge University Press.

Yılmaz, Serdar. (2017). Eurasian Economic Union: A Regional Economic Hegemony Initiative. Journal of Eastern European And Central Asian Research Vol.4 No. 22017. 
